\title{
Effects of topographic variability and forest attributes on fine-scale soil fertility in late-secondary succession of Atlantic Forest
}

\author{
Alice Cristina Rodrigues ${ }^{1}$, Pedro Manuel Villa ${ }^{1,2,3}$, Walnir Gomes Ferreira-Júnior ${ }^{4}$, \\ Carlos Ernesto R. G. Schaefer ${ }^{5}$ and Andreza Viana Neri ${ }^{1 *}$ (D)
}

\begin{abstract}
Background: Understanding how soil fertility changes due to topographical conditions and forest attributes is an essential premise for local-scale forest management practices. We evaluated the effects of topographic variables and forest attributes on soil fertility along a local topographical gradient in a Brazilian Atlantic Forest. We hypothesised that soil fertility is positively affected by topographic variability and forest attributes (structure and diversity). We used tree species richness, composition, abundance, and aboveground biomass as forest attributes. We analysed two 1-ha forest patches with contrasting topographical conditions. We used different linear mixed effects models (LMMs) to test the main effects of different forest attributes and topography variables on soil fertility.

Results: The results showed that higher topographic variability determines soil fertility along a fine-scale gradient. The first two axes of the PCA explained 66.8\% of the variation in soil data, with the first axis (PCA $)$ explaining 49.6\% of the variation in soil data and positively correlating with fertility-related soil properties. The second axis $\left(\mathrm{PCA}_{2}\right)$ explained $17.2 \%$ of the variation in topographical data and positively correlated with convexity (the elevation of a plot minus the average elevation of all immediate neighbour plots) and elevation. Our best models showed that topographic variables (elevation and convexity) are the main predictors that affect fine-scale soil fertility.

Conclusions: Our study demonstrates that the topographic variability, mainly elevation and convexity, determines fine-scale soil fertility in an Atlantic Forest. These results advance our understanding that context-dependent conditions based on topography and soil properties have a high variability at a fine scale, which can influence variations in forest attributes (i.e., species distribution, diversity and structure of tree communities). In addition, the information generated in this research may be important for planning forest restoration activities (passive and active) based on the high variability of environmental variables at a fine scale.
\end{abstract}

Keywords: Convexity, Soil variability, Succession, Topographical gradient, Tropical forests

\section{Background}

Elucidating the processes that influence plant-soil relationships is one of the most critical issues in forest ecology (Kardol et al. 2013; Ali et al. 2017; Poorter et al.

\footnotetext{
*Correspondence: andreza.neri@ufv.br

${ }^{1}$ Laboratory of Ecology and Evolution of Plants - LEEP, Departamento de Biologia Vegetal, Programa de Pós-Graduação em Botânica - Universidade Federal de Viçosa, Viçosa, Minas Gerais CEP: 36570-900, Brazil

Full list of author information is available at the end of the article
}

2017). Most of the studies have focused mainly on the effects of soil properties on tree community diversity and ecosystem functioning (Ali et al. 2017; Rodrigues et al. 2019, 2020). Soil properties change along environmental gradients at different spatiotemporal scales (Nettesheim et al. 2015). However, environmental conditions (i.e., climate, topography) and forest attributes (i.e., tree species composition, richness, abundance and biomass) can simultaneously explain chemical soil properties and fertility variability (Baker et al. 2009; Malhi et al. 2009; 
Laughlin et al. 2015). However, these effects on secondgrowth tropical forest are still poorly researched.

The Brazilian Atlantic Forests are one of the most species-rich biomes and threatened tropical forests on the planet (Scarano and Ceotto 2015). Actually, the Atlantic Forests, growth mainly as secondary forest in small remnant patches into the agricultural matrix (Scarano and Ceotto 2015). Second-growth forests that re-grow after disturbance depend on multiple drivers at different spatial scales (i.e., Arroyo-Rodrigues et al. 2017; Poorter et al. 2017). For example, at a regional-scale, climate (i.e., temperature and rainfall) is the predominant factor that determines plant species distribution (Powers et al. 2009; Zhang et al. 2014). On a local-scale, where the climate does not change spatially, abiotic and biotic factors such as soil properties, topographical conditions and forest attributes (i.e., diversity and structure of tree community) increase the relative effects on patterns and process of second-growth forests (Villa et al. 2018a, 2020). Most of the studies assess the effects of topography and soil proprieties on forest attributes, such as diversity, structure and aboveground biomass (Ali et al. 2017; Poorter et al. 2017; Villa et al. 2018a, 2018b). Conversely, few studies have analysed the effect of forest attributes and topography on soil fertility. This information can be essential for the Atlantic Forest restoration because the fine scale environmental variability (i.e., topography and soil) determines the selection and spatial distribution of the tree species.

Topography is one of the most relevant factors that influence ecological process in tropical forests (Jucker et al. 2018; Li et al. 2018; Rodrigues et al. 2019), playing an essential role in determining soil chemistry and fertility patterns (Moeslund et al. 2013; Jucker et al. 2018). Moreover, topography is strongly linked to soil fertility gradients and nutrient availability at the local scale (Balvanera et al. 2011). Thus, topographical variables, such as elevation, slope and convexity, can affect soil properties (Moeslund et al. 2013; Li et al. 2018), including short elevational gradients in a tropical forest (Daws et al. 2002). For example, soils in valleys tend to be wetter and more fertile than those near ridgetops (Gibbons and Newbery 2003; Segura et al. 2003). Furthermore, steeper sites have a higher nutrient output and, therefore, generally have fewer available nutrients in the soil than flatter sites (Balvanera et al. 2011). Thus, differences in the forest attributes can be found in a short topographical gradient (Rodrigues et al. 2019, 2020) based on the effects of soil properties variability on tree species distribution (Maestre and Reynolds 2006).

Several researches demonstrated that forest attributes change along succession (i.e., Chazdon, 2014; Villa et al. 2018a; Poorter et al. 2019), e.g., forest structure and diversity as a function of directional change in forest communities (Campetella et al. 2011). Differences in forest structure and diversity can also affect soil fertility along succession (Kardol et al. 2013; Laughlin et al. 2015). In this sense, it is necessary to quantify the fine-scale biotic and abiotic drivers and their contribution to soil fertility as an ecological indicator that better represents the available soil nutrients for plant growth in tropical forests (Poorter et al. 2017; Ali et al. 2019).

In this context, we evaluated how topographic variables and forest attributes (i.e., structure and diversity of tree communities) affect soil fertility along Atlantic Forests, Minas Gerais State, Southeastern Brazil. We evaluated soil-related fertility properties, tree species richness and composition (tree community diversity), abundance and aboveground biomass (tree community structure) as main forest attributes along a topographical gradient. We defined the following research questions: (1) how do soil-related fertility properties change along a topographical gradient? and (2) What is the main effect of forest attributes and topographic variables on soil fertility? We hypothesised that soil fertility is positively affected by topographic variability and forest attributes based on the premise that greater topographic variability and an increase in forest attributes (i.e., increase in richness, abundance, biomass) could induce greater incorporation and turnover of nutrients. This study allowed us to investigate whether topography and forest attributes affect soil properties associated with fertility as a potential ecological indicator for fine-scale restoration.

\section{Materials and methods \\ Study site}

The study was conducted in a Seasonal Atlantic Forest fragment extending over approximately 75 ha at Viçosa, Minas Gerais State, Southeastern Brazil $\left(20^{\circ} 45^{\prime} 14^{\prime \prime}\right.$ S, $\left.42^{\circ} 45^{\prime} 53^{\prime \prime} \mathrm{W}\right)$. According to the Köppen-Geiger classification, the climate is tropical altitude $\left(\mathrm{Cw}_{\mathrm{b}}\right)$, with a dry season between May and September and a wet season between December and March (Alvares et al. 2014). Mean annual temperature is $21^{\circ} \mathrm{C}$ and mean annual precipitation $1270 \mathrm{~mm}$, with the highest volumes of rain concentrated in December, January and February (AvilaDiaz et al. 2020; UFV 2020). The study area is located at an elevation of 620-820 m.a.s.l., and the relief varies from strongly undulating to mountainous. The site is characterised by two dominant soil classes: a red-yellow alsicose latosol covers hilltops and mountainsides, while a cambic yellow-red podzolic dominates the upper fluvial terraces (Ferreira-Júnior et al. 2007).

The forest fragment was used to cultivate coffee until 1926. With the acquisition of the area by the Universidade Federal Viçosa, it has been protected since then, 
allowing natural regeneration (Paula et al. 2004) as the main passive restoration strategy. Del Peloso (2012), through temporal analysis via images, observed that, in 1963, the Southeastern patch was entirely on the forest fragment's border, assigning a regeneration age to this patch of approximately 50 years (today $\sim 57$ years). On the other hand, the Northeastern patch was already part of the fragment's nuclear area. It is possible to suggest, based on the information that the area was abandoned in 1926 , that it has been in natural regeneration for approximately 87 years.

\section{Sampling design and forest survey}

We analysed two 1-ha forest patches with contrasting topographic conditions, with a difference of approximately 30 years, a Southeastern patch $(\sim 57$ years $)$ and a Northeastern one ( $\sim 87$ years). Each patch was subdivided into 100 contiguous plots of $10 \times 10 \mathrm{~m}$ to better capture the topography and soil properties at fine scale (van der Sande et al. 2018; Rodrigues et al. 2019). This experimental design is recommended to explain finescale soil variability because it can be captured in small plots in a short topographical gradient. Furthermore, soil fertility effects may be weaker at larger spatial scales and plots (van der Sande et al. 2018). All trees having a DBH (diameter at breast height; $1.3 \mathrm{~m}$ ) greater than or equal to $5.0 \mathrm{~cm}$ were inventoried and identified to the species level using specialised literature, through consultation of the VIC Herbarium and by taxonomists. The Angiosperm Phylogeny Group IV (APG IV 2016) was used for taxon classification.

\section{Estimation of aboveground biomass}

The aboveground biomass of individual tree stems was calculated using a general allometric equation proposed by Chave et al. (2014) based on tree diameter at breast height $(\mathrm{DBH}, \mathrm{cm})$, height $(H$, meters) and species wood density $\left(\mathrm{g} \mathrm{cm}^{-3}\right)$. We used data from the Global Wood Density Database (Chave et al. 2009; Zanne et al. 2009) to obtain each species' wood density (i.e., Jucker et al. 2018; Ali et al. 2019). The total aboveground biomass per plot was the sum of all trees' aboveground biomass (Ali et al. 2017). The following equation was used:

$$
\mathrm{AGB}=0.0673\left(\rho \times \mathrm{DBH}^{2} \times H\right)^{0.976}
$$

Species-level biomass was calculated as the sum of the biomass values of all individuals from an individual species. Estimation of aboveground biomass was performed using the $\mathrm{R}$ package BIOMASS (Réjou-Méchain et al. 2017).

\section{Soil properties}

To measure the soil properties associated with fertility within each plot, a composite sample of the topsoil (at 0-10 cm depth) was collected. The samples' soil properties were measured in the Laboratory of Soil Analysis of the Universidade Federal Viçosa, following standard protocols described in Ferreira-Júnior et al. (2007). The following parameters were assessed: exchangeable acidity potential $\left(\mathrm{H}+\mathrm{Al}, \mathrm{cmol}_{\mathrm{c}} \mathrm{dm}^{-3}\right), \mathrm{pH}\left(\mathrm{H}_{2} \mathrm{O}\right)$, exchangeable potassium $\left(\mathrm{K}, \mathrm{mg} \mathrm{dm}^{-3}\right)$, sodium $\left(\mathrm{Na}, \mathrm{mg} \mathrm{dm}^{-3}\right)$, calcium $\left(\mathrm{Ca}^{2+}, \mathrm{cmol}_{\mathrm{c}} \mathrm{dm}^{-3}\right)$, magnesium $\left(\mathrm{Mg}^{2+}, \mathrm{cmol}_{\mathrm{c}} \mathrm{dm}^{-3}\right)$, organic matter $\left(\mathrm{OM}, \mathrm{dag}_{\mathrm{kg}}^{-1}\right)$, effective cation exchange capacity (CEC, $\mathrm{cmol}_{\mathrm{c}} \mathrm{dm}^{-3}$ ), percentage of base saturation $(V, \%)$, and soil texture (sand, clay and silt contents).

\section{Measurements of topographical variables}

Using a total station, we measured vertical and horizontal angles and linear distances at the four vertices of each of the 200 plots (Kahmen et al. 1988). We calculated three topographic variables (slope, elevation and convexity) in each plot from the values obtained. Elevation was calculated using the mean elevation at each of the four corners of the plot. The slope (measured in degrees) was the mean angular deviation of the horizontal of each of the four triangular planes formed by the connection of three of its edges (Harms 2001). Convexity was determined by subtracting the elevation at the centre of the quadrat from the eight surrounding plots' mean elevation. On edge plots, convexity was calculated as the elevation of the plot of interest minus the mean elevation of the surrounding plots (Lan 2011).

\section{Data analysis}

To address the first question, "how do soil-related fertility properties change along a topographical gradient?, we used a principal component analysis (PCA) on the correlation matrix to describe the topographical and soil gradients between forest patches, reducing the number of redundant variables on the PCA axes. This analysis was preceded by variable standardisation to equalise their contributions on the PCA ordination axes (i.e., Schmitz et al. 2020), using the 'FactoMineR' package (Husson et al. 2018). Thus, we constructed two PCA analyses, a first PCA to represent the fertility and texture gradient due to the high correlation of the variables with the PCA axes. Subsequently, we analysed the Spearman correlation between properties related to fertility and texture with the PCA axes to evaluate the contribution of variables (Additional file 1: Fig. S1). We applied a PCA separately for texture because there were no significant relationships with the axes and no significant variation between forests patches (Additional file 1: Fig. S2). 
Then, we selected the first PCA axes related soil fertility (PCA1f) as a response variable (i.e., Schmitz et al. 2020; Villa et al. 2021). To compare forest attributes, we used the Mann-Whitney $U$ test in the tests for two independent forest patches. However, this test is widely used to test whether or not two independent samples are significantly different (Crawley 2012).

To address the second question, 'what is the main effect of forest attributes and topographic variables on soil fertility?, we used different linear mixed-effects models (LMMs, with random and fixed effects) to test the main effects of different predictors (i.e., topographical variables and forest structure and diversity attributes) on the first PCA axes related soil fertility (PCA1f) as the continuous response variable. The most suitable data distribution and link function was evaluated (Additional file 1: Fig. S3), detecting LMM with Gaussian error distribution (Crawley 2012). Based on this, we corroborate a high correlation between PCA1 and other indicators of soil fertility, such as CEC and SB index (Additional file 1: Fig. S4). To compare the variation of community composition between second-growth forests and old-growth forests patches a non-metric multidimensional scaling (NMDS) analysis was performed using 'metaMDS' function based on Bray-Curtis dissimilarities (Oksanen et al. 2018). Finally, we extracted the scores on frequency-weighted NMDS axis 1 as proxy of community composition variability (i.e., Schmitz et al. 2020; Villa et al. 2021). All different functions of NMDS are available within the "vegan" package (Oksanen et al. 2018).

The predictors with fixed effects for building the models were grouped into three categories: (i) topographic variables, (ii) forest structure attributes (abundance and aboveground biomass as continuous explanatory variables), and (iii) forest diversity predictors (i.e., species richness and composition) as continuous explanatory variables. We assessed collinearity between selected predictor variables using the Spearman correlation analysis; when two variables were strongly correlated $(r \geq 0.6)$, they were included in separate models (Additional file 1 Fig. S4). We tested alternative models with individual effects of predictors and different combinations of predictors with low correlation, and the stand age and plots were considered as a random effect (1|stand age: plots). All models were calculated using the package 'Ime4' (Bates et al. 2019) in the platform R (R-Core-Team 2018).

Finally, we compared the most parsimonious model (null model) with all the ecologically significant combinations of fixed variables based on the multi-model inference approach with the Dredge function of the "MuMIn" package (Barton 2017). The general adjustment of all models was using the information-theoretical approach based on the Akaike Information Criterion (AIC) to evaluate the best models (LMMs) tested, considering all models with AIC $<2.0$ as equally plausible (Burnham and Anderson 2002; Burnham et al. 2011). The predictors' coefficients to interpret parameter estimates on a comparable scale were estimated using the "jtools" package (Long 2020). For graphical illustration, we used the 'ggplot2' package (Hadley 2015).

\section{Results}

\section{Differences in soil-related fertility properties} and topographical variables

The first two axes of the PCA explained $66.8 \%$ of the variation in soil data (Fig. 1). The first axes $\left(\mathrm{PCA}_{1}\right)$ explained $49.6 \%$ of the variation in soil data and correlated positively with the variability of fertility-related soil properties, such as total exchangeable bases $(R=0.92, p<0.05)$, base saturation index $(R=0.82, p<0.05)$, effective cation exchange capacity $(R=0.79, p<0.05)$ and $\mathrm{pH}(R=0.77$, $p<0.05)$, and negatively with acidity potential $(R=-0.92$, $p<0.05)$ and aluminium saturation index $(R=-0.91$, $p<0.05)$. The second axes $\left(\mathrm{PCA}_{2}\right)$ explained $17.2 \%$ of the variation in topographical data (Fig. 1) and correlated positively with convexity $(R=0.72, p<0.05)$ and elevation $(R=0.53, p<0.05)$, but did not present a significant correlation with slope (Additional file 1: Fig. S1).

\section{Differences in forest attributes}

Our results showed differences in forest structure and diversity attributes (i.e., abundance and richness) between patches (Fig. 2A, B), except for aboveground biomass (Fig. 2C). Specifically, tree species richness at the plot scale is higher in a patch of high topographic variability (Northeastern), while the tree abundance increases in the patch

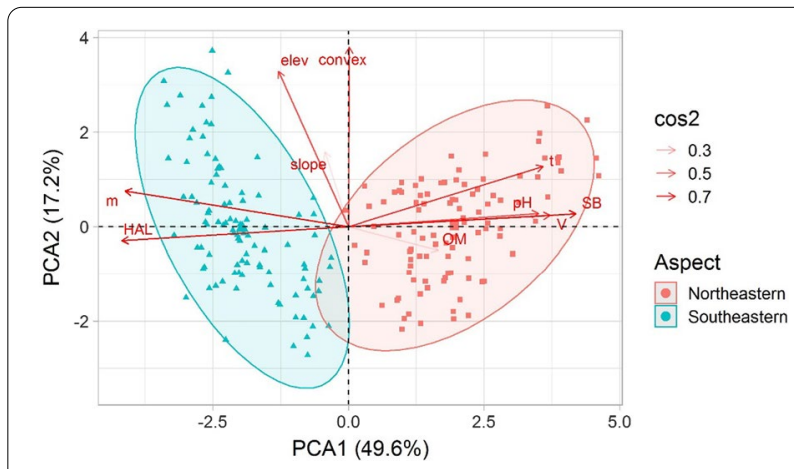

Fig. 1 Principal components analysis (PCA) of the topographic and soil variables of different patches (Northeastern and Southeastern). For analysis, elevation (elev), convexity (convex), slope, exchangeable acidity potential $(\mathrm{H}+\mathrm{Al})$, acidity potential index $(m), \mathrm{pH}\left(\mathrm{H}_{2} \mathrm{O}\right)$, organic matter $(\mathrm{OM})$, effective cation exchange capacity $(t=\mathrm{CEC})$, sum of basic exchangeable cations (SB) and base saturation index ( $V$ ) were included. $\operatorname{Cos} 2$ means the relative contribution of the variables represented by the vectors 

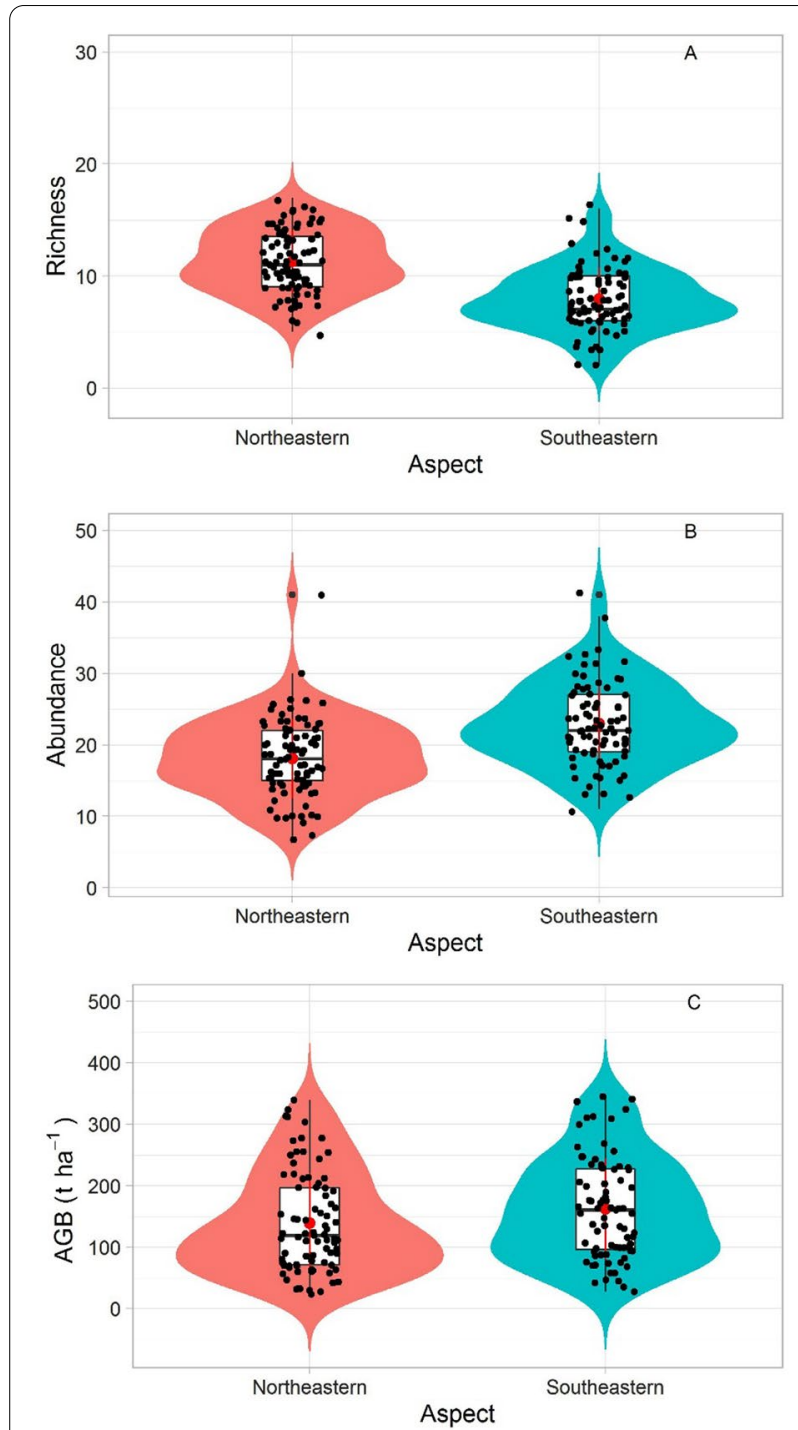

Fig. 2 Differences in tree species richness $(\mathbf{A})$, abundance $(\mathbf{B})$ and AGB $(\mathbf{C})$ between Northeastern and Southeastern patches in the Atlantic Forest, Minas Gerais, Brazil. Each black dot on the graph represents the mean value of the response variable on each plot around the mean the red dot and violins shape represent data variability

of low topographic variability (Southeastern). Despite the high aboveground biomass (AGB) stock variability between plots and patches, the mean values remain close $\left(\sim 150 \mathrm{t} \mathrm{ha}^{-1}\right)$ without significant differences (Fig. 2C).

\section{Effects of topographic variables and forest attributes on soil fertility}

Our best model was used to select topographic variables as main predictors $(\triangle \mathrm{AICc}<2)$ that explain soil fertility variation. Our results showed that elevation negatively influences soil fertility (LMM: Est. $=-0.42, t=-5.6$, $p<0.001$ ) explaining $60 \%$ of the variability (Table 1 ). Meanwhile, convexity (LMM: Est. $=1.40, \quad z=9.19$, $p<0.001)$ had significant positive on soil fertility. Conversely, the forest attribute predictors had no significant effect on fertility (Table 1, Fig. 3).

\section{Discussion}

Our results showed that fine-scale topographic variables shape soil fertility. Elevation was the best predictor determining soil fertility along a topographical gradient in the studied Atlantic Forests. Moreover, the tested models reveal that convexity was also the main predictor that

Table 1 Subset of models (linear mixed effect model, Imer) predicting soil fertility (response variable)

\begin{tabular}{llllr}
\hline Predictors & LogLik & AICc & \multicolumn{1}{c}{$\boldsymbol{\Delta \text { AICc }}$} & \multicolumn{1}{c}{ AICcwt } \\
\hline Elevation & -210.35 & 433.30 & 0 & $0.60^{*}$ \\
Convexity & -211.47 & 433.33 & 0.03 & $0.25^{*}$ \\
Slope & -210.49 & 435.7 & 2.4 & 0.13 \\
Species composition & -212.71 & 438.0 & 4.7 & 0.01 \\
Richness & -211.65 & 438.12 & 4.82 & $<0.001$ \\
Abundance & -212.80 & 438.4 & 5.1 & $<0.001$ \\
\hline
\end{tabular}

The result of the information-theoretic-based model selection is indicated. Models that explain significant main effects are indicated (*)

LogLik, log-likelihood; AICc, Akaike information criterion for small samples; $\triangle \mathrm{AICC}$, difference between the AICc of a given model and that of the best model; AICcWt, Akaike weights (based on AIC corrected for small sample sizes)

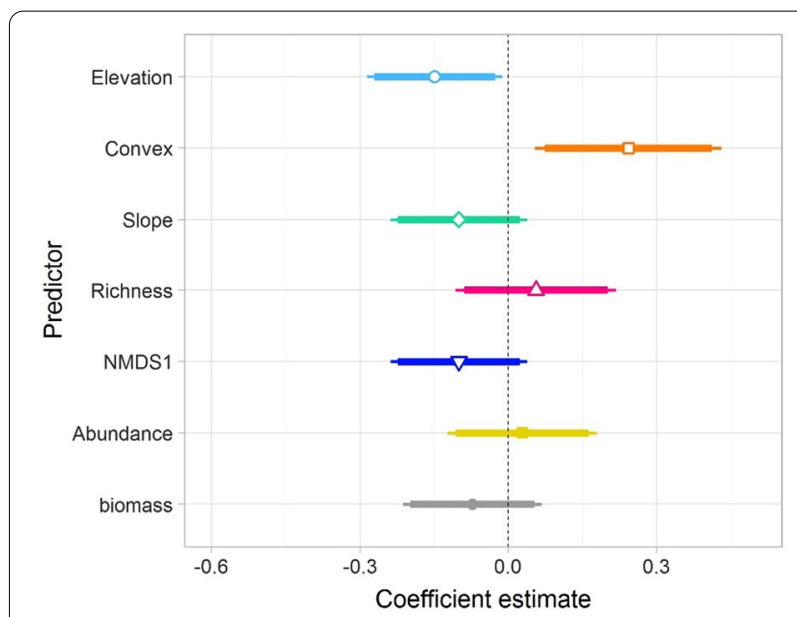

Fig. 3 Standardised regression coefficients of different generalised linear mixed effects models (LMMs, with random and fixed effects) to test the main effects of different predictors (i.e., topographical variables and forest structure and diversity attributes) on PCA1 soil fertility in the Atlantic Forest, Minas Gerais, Brazil. Results are presented for the mean distributions. We show the averaged parameter estimates (standardised regression coefficients) of model predictors, the associated 95\% confidence intervals and each factor's relative importance, expressed as the percentage of explained variance 
explained soil fertility variation. These results partially demonstrate the hypotheses established in this research because forest attributes had no significant effect on soil fertility on a fine scale. These results highlight that these topographic variables were considered to establish criteria for fine-scale Atlantic Forest restoration and management, mainly to select and manage tree species along topographical gradient.

The first axes $\left(\mathrm{PCA}_{1}\right)$ explained $49.6 \%$ of the variation in soil data and correlated positively with the variability of soil-related fertility properties, such as total exchangeable bases, base saturation index, exchange capacity effective cation and $\mathrm{pH}$. In several studies, total exchangeable bases were positively correlated with a wide range of soil properties that affect soil fertility, including $\mathrm{pH}$, effective cation exchange capacity, base saturation, organic-matter content and phosphorus availability (Holmes et al. 2005; Ali et al. 2019; Poorter et al. 2019). Previous studies provide evidence of a stronger relationship between topography and pH (Gibson 1988; Zalatnai and Körmöczi 2004). However, Xia et al. (2015) found that soil properties had higher spatial variability within a 1-ha patch and that the low level of topographic variation within a small area was strongly associated with soil $\mathrm{pH}$ but poorly associated with all soil nutrients. Furthermore, changes in $\mathrm{pH}$ caused by topographic hydrology may exist (Moeslund et al. 2013). For example, due to gravity and water accumulation in wetland depressions, soil organic matter often accumulates in these low-lying sites, where subsequent decomposition produces a decrease in $\mathrm{pH}$ (Courtwright and Findlay 2011). These processes could probably explain our finding that the Northeastern patch, with higher topographic variability (Rodrigues et al. 2019) being more related to higher $\mathrm{pH}$ values. Since this patch has several habitats (high convexity and depressions), this induces organic matter accumulation and, consequently, higher values of properties associated with soil acidity (i.e., acidity potential, aluminium saturation index).

The second axes $\left(\mathrm{PCA}_{2}\right)$ explained $17.2 \%$ of the topographical variation and correlated negatively with elevation, but there was no significant correlation with convexity and slope. Moreover, our main models explained the significant effects of elevation on fertilityrelated soil properties, such as the total exchangeable bases that better represent the available soil nutrients for plant growth (Poorter et al. 2017; Ali et al. 2019). In a similar study, soil $\mathrm{pH}$, conductivity, organic matter and macro- and micronutrients along an elevational gradient were significantly correlated with elevation (Grell et al. 2005). On the other hand, in contrast to our findings, Nettesheim et al. (2015) showed that in the Atlantic Forests, even small terrain variations, such as a slight surface change in slope orientation, are sufficient to determine different soil conditions, thereby increasing habitat differentiation.

Our results allow us to presume that topography and soil fertility relationships may be an important factor in local-scale restoration activities. For instance, tree species distributed in valleys along a topographical gradient tend to regenerate faster, presumably because they have higher soil fertility and higher soil nutrient levels than slopes (Griscom and Ashton 2011). Slopes have better-drained soils, and nutrients leach downslope from the ridges and may accumulate in the valleys (Scatena and Lugo 1995), thus increasing tree growth in the valleys (Scholten et al. 2017). We presumed that the Northeastern patch, with a heterogeneous terrain, seems to maximise the influence of topographical conditions on soil fertility. This patch has higher environmental heterogeneity that can be decisive in providing habitats for the establishment of a greater number of tree species (Brown et al. 2013; Rodrigues et al. 2019). Topography has also been recognised as an important dimension of plants' ecological niches, facilitating species coexistence in tropical forests (Brown et al. 2013). Higher topographic variability and the consequently higher species diversity could be a critical factor in soil fertility feedback. An increase in tree species diversity maintains soil fertility through several mechanisms, such as differences in litter quantity and quality, which can indirectly impact soil microbiota and decomposition processes (Scherer-Lorenzen et al. 2007; Oliveira et al. 2019).

We tested models that reveal that forest attributes had no affect soil fertility. However, in tropical forests, soil properties have a closer relationship with forest attributes (Laughlin et al. 2015). The processes by which diversity influences soil properties are related to litter production and litter quality (Scherer-Lorenzen et al. 2007; Laughlin et al. 2015; Oliveira et al. 2019); differences between soil fertility in different forest gradients are mainly caused by soil litter quality and microbial biomass (Li et al. 2013; Laughlin et al. 2015; Oliveira et al. 2019). However, our study corresponds to a late-secondary forest succession, where there is probably a stabilization of forest attributes and consequently its effects on soil fertility. Therefore, we propose future studies to evaluate soil fertility differences, considering forest attributes during early and late successional stages, since it is expected that the topography will not change over time. Moreover, we suggest evaluating the contribution of species diversity on litter stock and feedback, considering second-growth forest at different successional stages, since the litter composition can 
affect soil properties such as nutrients and other ecological indicators of soil fertility (Laughlin et al. 2015).

Our results allow us to elucidate fine-scale processes to establish specific management plan in forest restoration patches (i.e., natural regeneration, seedling planting). For example, we suggest identifying specific ecological patterns that allow classifying different habitat types and environmental conditions (i.e., topography, soil fertility) to define management strategies within the forest restoration plan (i.e., species selection, site preparation and species distribution). We emphasize that there is usually a tendency to establish the same management methods and techniques within a single forest restoration plan, ignoring the high environmental variability at the landscape and local scale. Thus, we consider that in tropical forests with high topographic variability, it is necessary to define the interest levels of restoration activities and to better evaluate the effects of topographic variables on soil fertility as one main ecological indicator. For the specific case of the Atlantic Forest, which is characterised by its high topographic variability and fragmentation, these premises must be urgently considered to contribute to the successful development and monitoring of current forest restoration projects.

\section{Conclusions}

Our study showed that the topographic variables, elevation and convexity, affected soil fertility in an Atlantic Forest fragment. On the other hand, despite the difference in tree species richness and abundance, forest attributes had no significant effect on soil fertility at a fine scale. Based on our results, the hypotheses can be partially accepted since some topographical variables have an important effect on the soil attributes. Finally, this study provides valuable information that an assessment of spatial soil variability in forests with high topographic variability must be a premise to optimise resources during management activities. Therefore, our study demonstrates that topographic variability and soil fertility are related; it can be extremely important for the development of management plans for fine-scale forest restoration and conservation, such as species selection, site preparation and species distribution at fine scale.

\footnotetext{
Abbreviations

SB:Total exchangeable bases; GLMMs: Generalised linear models of mixed effects; $\mathrm{CW}_{\mathrm{b}}$ : Climate is tropical altitude; APG IV: Angiosperm Phylogeny Group IV; DBH: Diameter at breast height; $\mathrm{H}$ : Height; K: Exchangeable potassium; Na: Sodium; Ca: Calcium; Mg: Magnesium; OM: Organic matter; CEC: Effective cation exchange capacity; V: Base saturation; PCA: Principal components analysis; AIC: Akaike Information Criterion; AGB: Aboveground biomass.
}

\section{Supplementary Information}

The online version contains supplementary material available at https://doi. org/10.1186/s13717-021-00333-1.

\begin{abstract}
Additional file 1: Fig. S1. Significance levels are based on Spearman correlation coefficients between soil parameters and principal components of PCA fertility from 200 plots within 2-ha plots in Atlantic Forest, Minas Gerais, Brazil. For analysis: elevation (elev), convexity (convex), slope, exchangeable acidity potential $(\mathrm{H}+\mathrm{Al})$, aluminum saturation index $(\mathrm{m}), \mathrm{pH}\left(\mathrm{H}_{2} \mathrm{O}\right)$, organic matter $(\mathrm{OM})$; effective cation exchange capacity $(t=C E C)$, sum of basic exchangeable cations (SB), base saturation index (V). Fig. S2. Dimensionality-reduction of soil physical properties based on Principal Component Analysis (PCA) along the topographical gradient. These results showed low variability between forest patches (Northeastern and Southeastern) based on coarse sand (Sand_c), fine sand (Sand_t), clay and silt. Fig. S3. Examples to test the most suitable distribution and link function using histogram and Q-Q considering the bests models with $\mathrm{AIC}<2.0$ (i.e., mod $=$ Soil fertility $\sim$ Elevation). Fig. S4. Spearman correlation among all individual variables measured in 200 plots along forest patches. For analysis, topographic variables, chemical properties-related soil texture as PCA1, and forest attributes were included. The following soil properties are included: soil organic carbon $(\mathrm{C})$, total nitrogen $(\mathrm{N})$, available phosphorus $(\mathrm{P})$, potassium $\left(\mathrm{K}^{+}\right)$, calcium $\left(\mathrm{Ca}^{2+}\right)$, magnesium $\left(\mathrm{Mg}^{2+}\right)$, iron (Fe), zinc $(\mathrm{Zn})$, exchangeable acidity $(\mathrm{H}+\mathrm{Al}), \mathrm{pH}$, organic matter $(\mathrm{OM})$. For analysis: elevation (elev), convexity (convex), slope, exchangeable acidity potential $(\mathrm{H}+\mathrm{Al})$, aluminum saturation index $(\mathrm{m}), \mathrm{pH}\left(\mathrm{H}_{2} \mathrm{O}\right)$, organic matter $(\mathrm{OM})$; effective cation exchange capacity $(t=C E C)$, sum of basic exchangeable cations (SB), base saturation index $(\boldsymbol{V})$.
\end{abstract}

\section{Acknowledgements}

We are grateful to Botany Graduate Program of Universidade Federal de Viçosa and Laboratory of Ecology and Evolution of Plants - LEEP. Thanks to Coordenação de Aperfeiçoamento de Pessoal de Nível Superior (CAPES), Conselho Nacional de Desenvolvimento Científico e Tecnológico (CNPq) for the funding. AVN Thanks CAPES-PRINT for the grant.

\section{Authors' contributions}

ACR and PMV conceptualization, formal analysis, writing-original draft. ACR and WGFJ investigation and data curation. CERGS resources, writing-review. AVN supervision, conceptualization, writing-original draft. All authors read and approved the final manuscript.

\section{Funding}

This study was financed in part by the Coordenação de Aperfeiçoamento de Pessoal de Nível Superior - Brasil (CAPES) - Finance Code 001.

\section{Availability of data and materials}

The data sets used and/or analyzed during the current study are available from the corresponding author on reasonable request.

\section{Declarations}

Ethics approval and consent to participate Not applicable.

\section{Consent for publication}

Not applicable.

\section{Competing interests}

The authors declare that they have no competing interests.

\section{Author details}

${ }^{1}$ Laboratory of Ecology and Evolution of Plants - LEEP, Departamento de Biologia Vegetal, Programa de Pós-Graduação em Botânica - Universidade Federal de Viçosa, Viçosa, Minas Gerais CEP: 36570-900, Brazil. ²Fundación Para la Conservación de la Biodiversidad, Mérida, Estado Mérida CEP 5101, Venezuela. ${ }^{3}$ Departamento de Engenharia Florestal, Universidade Federal de Viçosa, Viçosa, Minas Gerais CEP: 36570-900, Brazil. ${ }^{2}$ Laboratório de Botânica e 
Ecologia, Setor de Biologia e Meio Ambiente, Instituto Federal do Sul de Minas Gerais (IFSULDEMINAS) Campus Machado, Rodovia Machado - Paraguaçu, km 3, Machado, Minas Gerais CEP 37750-000, Brazil. ${ }^{5}$ Departamento de Solos, Universidade Federal de Viçosa, Viçosa, Minas Gerais CEP: 36570-900, Brazil.

Received: 2 June 2021 Accepted: 7 September 2021 Published online: 25 September 2021

\section{References}

Ali A, Yan E-R (2017) The forest strata-dependent relationship between biodiversity and aboveground biomass within a subtropical forest. For Ecol Manage 401:125-134. https://doi.org/10.1016/J.FORECO.2017.06.056

Ali A, Lin S-L, He J-K et al (2019) Big-sized trees overrule remaining trees' attributes and species richness as determinants of aboveground biomass in tropical forests. Glob Change Biol 25:2810-2824. https://doi.org/10. 1111/gcb.14707

Alvares CA, Stape JL, Sentelhas PC, Gonçalves JLM, Sparovek G (2014) Köppen's climate classification map for Brazil. Meteorolo Zeitschrift 6:711-728

Angiosperm Phylogeny Group IV (2016) An update of the Angiosperm Phylogeny Group classification for the orders and families of flowering plants: APG IV. Bot J Linn Soc 181:1-20. https://doi.org/10.1111/j.1095-8339. 2009.00996.x

Arroyo-Rodríguez V, Melo FPL, Martínez-Ramos M et al (2017) Multiple successional pathways in human-modified tropical landscapes: new insights from forest succession, forest fragmentation, and landscape ecology research. Biol Rev 92:26-340. https://doi.org/10.1111/brv.12231

Avila-Diaz A, Justino F, Lindemann DS, Rodrigues JM, Ferreira GR (2020) Climatological aspects and changes in temperature and precipitation extremes in Viçosa-Minas Gerais. An Acad Bras Ciênc 92:e20190388. https://doi.org/ 10.1590/0001-3765202020190388

Baker TR, Phillips OL, Laurance WF (2009) Do species traits determine patterns of wood production in Amazonian forests? Biogeosciences 6:297-307. https://doi.org/10.5194/bg-6-297-2009

Balvanera P, Quijas S, Pérez-Jiménez A (2011) Distribution patterns of tropical dry forest trees along a mesoscale water availability gradient. Biotropica 43:414-422. https://doi.org/10.1111/j.1744-7429.2010.00712.x

Barton K (2017) 'MuMIn': multi-model inference. R package version 1.40.0. https://cran.r-project.org/web/packages/MuMIn/MuMln.pdf. Accessed 15 Feb 2020

Bates D, Maechler M, Ben Bolker B et al (2019) 'Ime4': linear mixed-effects models using 'Eigen' and S4. R package version 1.1-21. https://cran.r-project. org/web/packages/Ime4/Ime4.pdf. Accessed 31 May 2020

Brown C, Burslem DFRP, Illian JB et al (2013) Multispecies coexistence of trees in tropical forests: spatial signals of topographic niche differentiation increase with environmental variability. Proc Bio Sci 280(1764):20130502. https://doi.org/10.1098/rspb.2013.0502

Burnham KP, Anderson DR (2002) Model selection and multimodel inference: a practical information-theoretic approach. Springer, New York

Burnham KP, Anderson DR, Huyvaer KP (2011) AIC model selection and multimodel inference in behavioral ecology: some background, observations, and comparisons. Behav Ecol Sociobiol 65:23-35. https://doi.org/10. 1007/s00265-010-1029-6

Campetella G, Botta-Dukát Z, Wellstein C et al (2011) Patterns of plant traitenvironment relationships along a forest succession chronosequence. Agric Ecosyst Environ 145:38-48. https://doi.org/10.1016/j.agee.2011.06. 025

Chave J, Coomes D, Jansen S et al (2009) Towards a worldwide wood economics spectrum. Ecol Lett 12:351-366. https://doi.org/10.1111/j.1461-0248. 2009.01285.x

Chave J, Réjou-Méchain M, Búrquez A et al (2014) Improved allometric models to estimate the aboveground biomass of tropical trees. Glob Change Biol 20:3177-3190. https://doi.org/10.1111/gcb.12629

Chazdon RL (2014) Second growth: the promise of tropical forest regeneration in an age of deforestation. University of Chicago Press, Chicago, p 472. https://doi.org/10.1007/s13157-011-0156-9

Courtwright J, Findlay S (2011) Effects of microtopography on hydrology, physicochemistry, and vegetation in a tidal swamp of the Hudson River. Wetlands 31:239-249

Crawley MJ (2012) The R book, 2nd edn. Wiley, London
Daws MI, Mullins CE, Burslem DFRP, Paton S, Dalling JW (2002) Topographic position affects the water regime in a semideciduous tropical forest in Panamá. Plant Soil 238:79-90. https://doi.org/10.1023/A:1014289930621

Del Peloso RV (2012) Dinâmica e sucessão de um fragmento de Floresta Atlântica. Universidade Federal de Viçosa, Dissertação de mestrado

Ferreira-Júnior WG, Silva AF, Schaefer CEGR et al (2007) Influence of soils and topographic gradients on tree species distribution in a Brazilian Atlantic tropical semideciduous forest. Edinb J Bot 64:1-22. https://doi.org/10. 1017/S0960428607000832

Gibbons JM, Newbery DM (2003) Drought avoidance and the effect of local topography on trees in the understorey of Bornean lowland rain forest. Plant Ecol 164:1-18. https://doi.org/10.1023/A:1021210532510

Gibson DJ (1988) The relationship of sheep grazing and soil variability to plant spatial patterns in dune grassland. J Ecol 76:233-252. https://doi.org/10. 2307/2260466

Grell A, Shelton MG, Heitzman E (2005) Changes in plant species composition along an elevation gradient in an old-growth bottomland hardwoodPinus taeda forest in southern Arkansas. J Torr Bot Soc 132:72-89. https:// doi.org/10.3159/1095-5674(2005)132[72:CIPSCA]2.0.CO;2

Griscom HP, Ashton MS (2011) Restoration of dry tropical forests in Central America: a review of pattern and process. For Ecol Manage 261:15641579. https://doi.org/10.1016/j.foreco.2010.08.027

Hadley W (2015) R ggplot2 package: an implementation of the grammar of graphics. https://ggplot2.org, https://github.com/hadley/ggplot2

Harms KE, Condit R, Hubbell SP, Foster RB (2001) Habitat associations of trees and shrubs in a 50-ha neotropical forest plot. J Ecol 89:947-959. https:// doi.org/10.1046/j.0022-0477.2001.00615.X

Holmes KW, Kyriakidis PC, Chadwick OA, Soares JV, Roberts DA (2005) Multiscale variability in tropical soil nutrients following land-cover change. Biogeochemistry 74:173-203. https://doi.org/10.1007/s10533-004-3544-x

Husson F, Josse J, Le S (2018) "FactoMineR" package multivariate: exploratory data analysis and data mining. RStudio package version 1.0.14. https:// cran.r-project.org/web/packages/FactoMineR/FactoMineR.pdf

Jucker T, Bongalov B, Burslem DFRP et al (2018) Topography shapes the structure, composition and function of tropical forest landscapes. Ecol Lett 21:989-1000. https://doi.org/10.1111/ele.12964

Kahmen H, Faig W (1988) Surveying. Walter de Gruyter \& Co., Berlin

Kardol P, De Deyn GB, Laliberté E, Mariotte P, Hawkes CV (2013) Biotic plantsoil feedbacks across temporal scales. J Ecol 101:309-315. https://doi.org/ 10.1111/1365-2745.12046

Lan GY, Hu YH, Cao M, Zhu H (2011) Topography related spatial distribution of dominant tree species in a tropical seasonal rain forest in China. For Ecol Manag 262:1507-1513. https://doi.org/10.1016/j.foreco.2011.06.052

Laughlin DC, Richardson SJ, Wright EFP, Bellingham PJ (2015) Environmental filtering and positive plant litter feedback simultaneously explain correlations between leaf traits and soil fertility. Ecosystems 18:1269-1280. https://doi.org/10.1007/s10021-015-9899-0

Li Y, Yang F, Ou Y et al (2013) Changes in forest soil properties in different successional stages in lower tropical China. PLoS ONE 8(11):e81359. https://doi.org/10.1371/journal.pone.0081359

Li X, McCarty GW, Karlen DL, Cambardella CA (2018) Topographic metric predictions of soil redistribution and organic carbon in lowa cropland fields. Catena 160:222-232. https://doi.org/10.1016/j.catena.2017.09. 026

Long JA (2020) "jtools" package: analysis and presentation of social scientific data

Maestre FT, Reynolds JF (2006) Spatial variability in soil nutrient supply modulates nutrient and biomass responses to multiple global change drivers in model grassland communities. Glob Change Biol 12:24312441. https://doi.org/10.1111/j.1365-2486.2006.01262.x

Malhi Y, Aragão LEOC, Metcalfe DB et al (2009) Comprehensive assessment of carbon productivity, allocation and storage in three Amazonian forests. Glob Change Biol 15:1255-1274. https://doi.org/10.1111/j. 1365-2486.2008.01780.x

Moeslund JE, Arge L, Bøcher PK, Dalgaard T, Svenning J-C (2013) Topography as a driver of local terrestrial vascular plant diversity patterns. Nord J Bot 31:129-144. https://doi.org/10.1111/j.1756-1051.2013.00082.x

Nettesheim FC, Conto T, Pereira MG, Machado DL (2015) Contribution of topography and incident solar radiation to variation of soil and plant litter at an area with heterogeneous terrain. Rev Bras Ciênc Solo 39:750-762. https://doi.org/10.1590/01000683rbcs20140459 
Oksanen J, Blanchet FG, Friendly M, Kindt R, Legendre P, McGlinn D, Minchin PR, O'Hara RB, Simpson GL, Solymos P, Stevens MHH, Szoecs E, Wagner E (2018) 'Vegan': Community Ecology Package. R package version 2.4-6. https://cran.r-project.org/web/packages/vegan/vegan.pdf. Accessed 16 June 2020

Oliveira RAC, Marques R, Marques MCM (2019) Plant diversity and local environmental conditions indirectly affect litter decomposition in a tropical forest. Appl Soil Ecol 134:45-53. https://doi.org/10.1016/j. apsoil.2018.09.016

Paula A, Silva AF, De Marco JP, Santos FAM, Souza AL (2004) Sucessão ecológica da vegetação arbórea em uma Floresta Estacional Semidecidual, Viçosa, MG, Brasil. Acta Bot Brasílica 18(3):407-423. https://doi. org/10.1590/S0102-33062004000300002

Poorter L, van der Sande MT, Arets EJMM et al (2017) Biodiversity and climate determine the functioning of Neotropical forests. Glob Ecol Biogeogr 26:1423-1434. https://doi.org/10.1111/geb.12668

Poorter L, Rozendaal DMA, Bongers F et al (2019) Wet and dry tropical forests show opposite successional pathways in wood density but converge over time. Nat Ecol Evol 3:928-934. https://doi.org/10.1038/ s41559-019-0882-6

Powers JS, Becknell JM, Irving J, Peréz-Aviles D (2009) Diversity and structure of regenerating tropical dry forests in Costa Rica: geographic patterns and environmental drivers. For Ecol Manage 276:88-95. https://doi. org/10.1016/j.foreco.2008.10.036

R Core Team (2018) R: a language and environment for statistical computing. R Foundation for Statistical Computing, Vienna, Austria. https:// www.R-project.org/. Accessed 15 Feb 2019.

Réjou-Méchain M, Tanguy A, Piponiot C, Chave J, Hérault B (2017) Biomass: an $\mathrm{R}$ package for estimating above-ground biomass and its uncertainty in tropical forests. Methods Ecol Evol 8:1 163-1167. https://doi.org/10. $1111 / 2041-210 X .12753$

Rodrigues AC, Villa PM, Neri AV (2019) Fine-scale topography shape richness, community composition, stem and biomass hyperdominant species in Brazilian Atlantic Forest. Ecol Indic 102:208-217. https://doi. org/10.1016/j.ecolind.2019.02.033

Rodrigues AC, Villa PM, Ferreira-Júnior W, Neri AV (2020) Fine-scale habitat differentiation shapes the composition, structure and aboveground biomass but not species richness of a tropical Atlantic forest. J For Res 31:1599-1611. https://doi.org/10.1007/s11676-019-00994-x

Rodrigues AC, Villa PM, Neri AV (2020) Distribuição espacial de fatores ambientais e atributos florestais usando rotinas no R. In: Diniz ES, Villa PM, eds. Aplicações da linguagem $R$ em análises de vegetação. Atena, Ponta Grossa, pp. 56-68. https://doi.org/10.22533/at.ed.3552009036

Scarano FR, Ceotto P (2015) Brazilian Atlantic Forest: impact, vulnerability, and adaptation to climate change. Biodivers Conserv 24:2319. https:// doi.org/10.1007/s10531-015-0972-y

Scatena FN, Lugo AE (1995) Geomorphology, disturbance, and the soil and vegetation of two subtropical wet steep land watersheds of Puerto Rico. Geomorphology 13:199-213. https://doi.org/10.1016/B978-0444-81867-6.50017-4

Scherer-Lorenzen M, Bonilla JL, Potvin C (2007) Tree species richness affects litter production and decomposition rates in a tropical biodiversity experiment. Oikos 116:2108-2124. https://doi.org/10.1111/j.2007.00301299.16065.x
Schmitz D, Schaefer CERG, Putzke J et al (2020) How does the pedoenvironmental gradient shape non-vascular species assemblages and community structures in Maritime Antarctica? Ecol Indic 108:105726. https://doi.org/10.1016/j.ecolind.2019.105726

Scholten T, Goebes P, Kühn P et al (2017) On the combined effect of soil fertility and topography on tree growth in subtropical forest ecosystems-a study from SE China. J Plant Ecol 10:111-127. https://doi.org/ 10.1093/jpe/rtw0652017

Segura G, Balvanera P, Duran E, Perez A (2003) Tree community structure and stem mortality along a water availability gradient in a Mexican tropical dry forest. Plant Ecol 169:259-271. https://doi.org/10.1023/A: 1026029122077

Universidade Federal de Viçosa - UFV (2020) Departamento de Engenharia Agrícola. Estação Climatológica Principal de Viçosa. Boletim meteorológico. Viçosa

van der Sande MT, Arets EJMM, Peña-Claros M et al (2018) Soil fertility and species traits, but not diversity, drive productivity and biomass stocks in a Guyanese tropical rainforest. Funct Ecol 32:461-474. https://doi. org/10.1111/1365-2435.12968

Villa PM, Martins SV, Oliveira Neto SN et al (2018a) Woody species diversity as an indicator of the forest recovery after shifting cultivation disturbance in the northern Amazon. Ecol Indic 95:687-694. https://doi.org/ 10.1016/J.ECOLIND.2018.08.005

Villa PM, Martins SV, Oliveira Neto SN et al (2018b) Intensification of shifting cultivation reduces forest resilience in the northern Amazon. For Ecol Manage 430:312-320. https://doi.org/10.1016/j.foreco.2018.08.014

Villa PM, Ali A, Martins SV et al (2020) Stand structural attributes and functional trait composition overrule the effects of functional divergence on aboveground biomass during Amazon forest succession. For Ecol Manag 477:118481. https://doi.org/10.1016/j.foreco.2020.118481

Villa PM, Martins SV, Pilocelli A et al (2021) Attributes of stand-age-dependent forest determine technosol fertility of Atlantic forest re-growing on mining tailings in Mariana, Brazil. J For Res. https://doi.org/10.1007/ s11676-021-01359-z

Xia S, Chen J, Schaefer D, Detto M (2015) Scale-dependent soil macronutrient variability reveals effects of litterfall in a tropical rainforest. Plant Soil 391:51-61. https://doi.org/10.1007/s11104-015-2402-z

Zalatnai M, Körmöczi L (2004) Fine-scale pattern of the boundary zones in alkaline grassland communities. Community Ecol 5:235-246. https:// doi.org/10.1556/ComEc.5.2004.2.11

Zanne AE, Lopez-Gonzalez G, Coomes DA et al (2009) Data from: towards a worldwide wood economics spectrum. Dryad Digital Repos. https:// doi.org/10.5061/dryad.234

Zhang Y, Chen HYH, Taylor A (2014) Multiple drivers of plant diversity in forest ecosystems. Glob Ecol Biogeogr 23:885-893. https://doi.org/10.1111/geb. 12188

\section{Publisher's Note}

Springer Nature remains neutral with regard to jurisdictional claims in published maps and institutional affiliations.

\section{Submit your manuscript to a SpringerOpen ${ }^{\circ}$ journal and benefit from:}

- Convenient online submission

- Rigorous peer review

- Open access: articles freely available online

- High visibility within the field

Retaining the copyright to your article

Submit your next manuscript at springeropen.com 